Article

\title{
Energetic Retrofit Strategies for Traditional Sicilian Wine Cellars: A Case Study
}

\author{
Francesco Nocera * ${ }^{\circledR}$, Rosa Caponetto $₫$, Giada Giuffrida $₫$ and Maurizio Detommaso \\ Department of Civil Engineering and Architecture, University of Catania, Viale Andrea Doria 6, \\ 95125 Catania, Italy; rosa.caponetto@unict.it (R.C.); giada.giuffrida@unict.it (G.G.); \\ maurizio.detommaso@phd.unict.it (M.D.) \\ * Correspondence: fnocera@unict.it; Tel.: +39-095-738-2366
}

Received: 5 May 2020; Accepted: 19 June 2020; Published: 22 June 2020

\begin{abstract}
Sicily is characterized by rural buildings, Palmenti, destined to wine production, which are scattered along the countryside and part of the local historical heritage. There are different types of rural buildings, but all have in common the use of ancient and well-established bioclimatic techniques for wine conservation and aging. Most of them were built with the double function of living space for the owner and productive spaces for all the activities correlated to the cultivations. Indeed, many rural houses, destined to the wine production, are characterized by wineries and wine cellars (the first for the wine production, the second to store the wine for the aging process). The growing production of high-quality Sicilian wines, very appreciated all over the world, leads to upgrade the ancient Palmenti to seek optimal hygrothermal conditions and, therefore, to guarantee high performance of the produced and stored wines. The purpose of this study is to investigate how the retrofit measures taken to comply with the energy regulations could affect the thermal behavior of a wine cellar constructed with consolidated bioclimatic technics. The results show the importance of not insulating the solid ground floor for maintaining suitable temperatures for the fermentation and aging of wine. This study can be useful for future analysis when comparing the optimal hygrothermal conditions of wine cellars located in homogeneous viticultural areas (with same climate, geology, soil, physical features, and height) in other parts of the world.
\end{abstract}

Keywords: bioclimatic strategy; traditional constructive technology; wine vinification; energetic retrofit

\section{Introduction}

The European Commission provides for reducing building energy consumption through the Energy Performance Building Directive 2002/91/EC [1] and 2010/31/EU [2]. The first directive is focused on new buildings while the second is concerned with existing buildings, not only when subjected to major renovation, but also when the building's technical elements and/or technical systems are retrofitted or replaced [3-5]. In the Eastern Sicilian territory, on the slopes of Etna volcano, the grapevine has the most widespread cultivation. The millenary viticultural tradition of the Mount Etna area dates back to Greek and Roman domination. Since 1968, Etna wines have acquired the Registered Designations of Origin (R.D.O.) denomination, established by Decree of the President of the Italian Republic on 11 August 1969 (one of the oldest in Italy) and today, Sicilian wines are highly valued throughout the world [6].

The vineyard, following the orography of the ground, hosts a number of diverse rural constructions adapted on the height of the site [7]. Between 700 and $1000 \mathrm{~m}$ above sea level, there are two prevalent kinds of farm buildings: two-story rural houses with the winery and warehouse on the ground floor and the owner's residence on the top floor, or small-sized buildings with a single room for wine pressing and storage in small barrels (Palmenti). The rural buildings of the Eastern Sicilian territory 
have a historical importance due to their cultural and architectural value. These buildings present elements of historical, ethnic, and anthropological interest, and are often subject to protection by the competent authorities. As it will be shown, this Etnean rural and vernacular heritage is significantly homogeneous concerning the use of local building materials, constructive technologies, traditional passive design features, indoor planimetric organization, and morphological aspects [8]. The rural houses are characterized by generally squared volumetry and lie on the natural irregular ground. Thus, farm buildings are organized on different levels which ensure that pressed grapes (must) naturally flow downwards through the vats into the tank. Despite the rural houses not having been constructed based on geometric plans, they always complied with a few features of simplicity and common sense considering the exposure, the sunlight, the view and many other bioclimatic aspects [9].

The Mediterranean climate heavily influenced design choices of the rural houses, which are constructed with natural materials and bioclimatic solutions, with the aim of mitigating winter and summer climatic extremes. Rural buildings display structural and thermophysical characteristics suitable not only for hygrothermal comfort and wellbeing of the occupants, but also for aging and conservation of the wine. The rural house exposure takes advantage of the natural ventilation provided by the winds of the Mount Etna area, which ensures that the building is always cooled. The rural houses are built by lava stone masonry $(60 \mathrm{~cm}$ thick) with a loadbearing and buffering function. Moreover, the great mass, typical of high-density materials that characterize traditional architecture of Mediterranean area, improves the energy performance of the building envelope and guarantees thermal and acoustic comfort [10]. The building envelope behaves as a thermal flywheel and modulator element of the heat flow between the outside and the inside. This leads to a reduction of thermal load, especially in summer periods, increasing the temperature gap between the interior and exterior to more than $10^{\circ} \mathrm{C}$, and therefore improving indoor thermal comfort [11]. The openings are small, especially on the south exposure, preventing direct radiation and excessive heat transmission in summer days. The solid ground floor insulation is guaranteed by the fact that often the buildings are separated from the foundation ground by a widespread "crawl space", which physically separates the building from the foundation ground, therefore diminishing both energetic dispersions and rising dampness. In addition, the building's ceiling is often tall enough to guarantee adequate and natural ventilation for the indoor spaces. Furthermore, the roof stratigraphy is usually composed by a loadbearing wooden structure (beams and rafters) covered by intertwined canes and roof tiles [12]. In addition, the rural houses are often characterized by other elements that help mitigate climatic conditions that are typical of traditional dwellings in the Mediterranean area, such as loggias, balconies, verandas, pergolas, openings [13].

\section{State of Art on Farm Wineries Thermal Performance}

All materials and low energy and passive solutions not only made the rural houses comfortable, but allows for the control of the internal microclimate; this aspect is of fundamental importance concerning winemaking and conservation of wine, whose production and conservation activities were always located along the north façades or, when it was possible, in the basement, in order to preserve the quality of wine $[14,15]$. Temperature control during the winemaking process and storage of wine is of paramount importance for the final quality of the wine. Indeed, temperature affects the activity of enzymes, which are involved at various stages in the whole wine production process. In fact, enzymes and bacteria are already present in the grape and may influence its degradation during the mush-maceration phase or affect the final aroma of wine through oxidation. As it is known, the activity of micro-organisms always depends on the temperature of the surrounding environment. From a metabolic point of view, a temperature range from 20 to $25^{\circ} \mathrm{C}$ is very favorable for alcoholic fermentation [16]. But at that temperature the fermentation activity becomes too strong and some aromatic compounds can diminish. Thus, in general, alcoholic fermentation should be operated at temperatures from 15 to $18{ }^{\circ} \mathrm{C}$ to achieve a satisfactory result [17] and make the wine age slowly, without losing quality [18]. Moreover, in Sicily, wine is traditionally bred and stored in wooden barrels. 
Authors in general agree that relative humidity is of secondary importance when it comes to wine aging: in general, a high relative humidity is good because it reduces losses due to evaporation, but it is important to note that those high values should not produce mold in the barrels; ventilation can help in reducing mold-growth risk [18]. At the stage of aging, the stability of air is very important, and it should range between $12-16{ }^{\circ} \mathrm{C}$ (lower temperatures during winter would make wine aging slower) with a relative humidity between $70-82 \%$ (to prevent from mold growth in poorly ventilated spaces). In general, the more stable the wine cellar is, the less contraction-expansion phenomena will affect the quality of the wine. That is the reason why historically, some types of building were claimed to be more suitable than others to host some food industry like wineries; in particular, underground or partially underground building solutions, with massive envelopes, were constructed to maximize their thermal inertia, thus preventing effects from outdoor climate swings [19,20].

A common feature between traditional wineries from all over the world is the attention given to the relation between the envelope and the foundation ground. In this sense, many authors [21] confirmed that is precisely the thermal stability given by the contact with the ground, which makes traditional buildings (underground and partially underground) so competitive when compared to contemporary wineries (usually built aboveground and often provided by HVAC systems). Some authors proposed an analytical model to predict the thermal interaction between the wine cellar and underground [22], but in the following paragraphs we will explain that in our case study, the contact with the ground is slightly different. As Tinti et al. [22] point out, from the second half of the Twentieth Century, underground buildings were progressively abandoned and substituted with single-story aboveground buildings where indoor temperature and humidity are controlled by air-conditioning systems. Use of HVAC systems to maintain appropriate indoor temperatures and humidity is correlated to surrounding environmental conditions and, in some areas, it was quantified that $50 \%$ of the total energy demand is for wine production [23]. It is thus understandable why so much effort in recent years was focused on decreasing energy consumption in the food industry, in general, and in farm wineries [24]. Currently, renewed attention is given to historic small and medium farm wineries, which play a key role in the Italian wine sector [19] for their overall production, for the close relations exchanged with surroundings economies and landscapes, and for their good thermophysical performance.

Our study moves from these considerations with the aim to confirm (1) the effectiveness and efficiency of traditional wine cellars to maintain adequate indoor thermal conditions, thanks to ancient passive design solutions, and, subsequently, (2) to investigate which possible retrofit energy solutions could simultaneously comply with the Italian energy-saving regulation, improve indoor thermal stability, and guarantee the aspect of correct temperatures for the aging and storage of wines. The improvement of the hygrothermal condition for traditional wine cellars and, therefore, the resulting energetic retrofitting, is more notably motivated by the high quality required by the DOC denomination of Sicilian wines. The results of the study underline how a "proper balance between traditional bioclimatic ideas and modern technologies" [25] must be pursued and prioritized, in justified cases, over the national and international energetic regulations.

The results of the study are not merely useful for an in-depth study of the appropriate retrofit strategies aimed at optimizing the conservation and production conditions of wine in local wineries, but above all they could represent a useful feedback for similar research conducted in other parts of the world that share the same characteristics in terms of geology, pedology, climate, and topography. Obviously, the previous technical considerations are strictly related to other factors that contribute to the quality of the final product, which are the so-called organic factors (vine, rootstock) and the anthropogenic ones (cultivation techniques and oenological practices) [26-28]. 


\section{Materials and Methods}

In many cases, the palmenti of Eastern Sicilian territory are used for vinification, aging, and conservation of the wine. The retrofitting and/or the functional reorganization of vernacular buildings involve a change in the internal environmental conditions (temperature, relative humidity, quality of the air, lighting, etc.). Thus, attention must be paid to the improvement of energy performance of the building envelope. Since the thermal performance of buildings and the influences of thermal mass and passive strategies can be evaluated only through dynamic thermal simulations [29-31], the authors investigated the thermal performance of a vernacular building in free-running conditions, i.e., without any energy systems for indoor air conditioning. The thermophysical properties of the building were deduced by archival data, endoscopic inspections, and in situ measurements. Starting from an instrumental diagnosis based on heat flow meter and temperature probe data, a calibrated building model was created and yearly dynamic simulations were performed to evaluate the influence of different retrofit measures on the internal microclimate that is of fundamental importance for wine making and conservation of wine. The heat flow meter allowed estimation of wall thermal transmittance; the temperature probes were employed to measure air temperature inside the construction. Indoor humidity measurements were also carried out. The measurements were conducted using a climate measuring instrument, Testo 445 , and a Thermozig heat-flux meter, according to ISO 9869. The weather data recorded by a local meteorological station were used as input for building simulation. Detailed dynamic thermal behavior and compliance with the normative in force of the buildings were analyzed using the software tool Design Builder, which is based on the calculation engine of Energy Plus. The building simulation model was calibrated using the temperature measured inside the wine cellar. The model validation was carried out by calculation of some statistical indices. The Mean Absolute Error (MAE), Mean Bias Error (MBE), Coefficient of Variation of the Root Mean Squared Error (CVRMSE), coefficient of determination $\left(R^{2}\right)$ [32], Pearson correlation coefficient $(r)$, and index of agreement $(d)$ were calculated with the aim of evaluating the reliability of the numerical model [33].

Starting from the results of the annual dynamic simulations, it was possible to assess the suitable energy retrofit solutions to obtain the optimal thermo-hygrometric values for winemaking and conservation of wine. For the sake of brevity, from the yearly analysis, the authors extrapolated and analyzed the thermal behavior of the palmento in two representative weeks: 27 January- 5 February and 5-14 September. The two weeks selected had the most extreme temperature and humidity values, and are fundamental for the fermentation, aging, and storage of wine on the Etna Volcano area. The winter week chosen is the coldest representative week of winter season and, moreover, is the week in which the wine is already suitable for consumption, with further possibility of improving its qualities by means of aging and storage. The summer week chosen corresponds to the typical harvest week and to the beginning of the long and delicate process of wine aging in order to confer the distinctive typical flavor; additionally, it is also the ending-week of the summer season, which is characterized by the highest temperature values.

\section{Case Study: The Wine Cellar}

\subsection{Description of the Building Features and Constructions}

The building (Figure 1) is located in Santa Maria di Licodia (latitude $37.66^{\circ}$, longitude $14.92^{\circ}$, Southern Italy), built during the late Eighteenth Century and currently used for production and storage of wine. The palmento has an overall net floor surface as large as $726 \mathrm{~m}^{2}$. The property is located outside the town center, in Contrada Cavaliere, in a large area occupied by various kinds of cultivations close to the wooded areas of Etna volcano. 


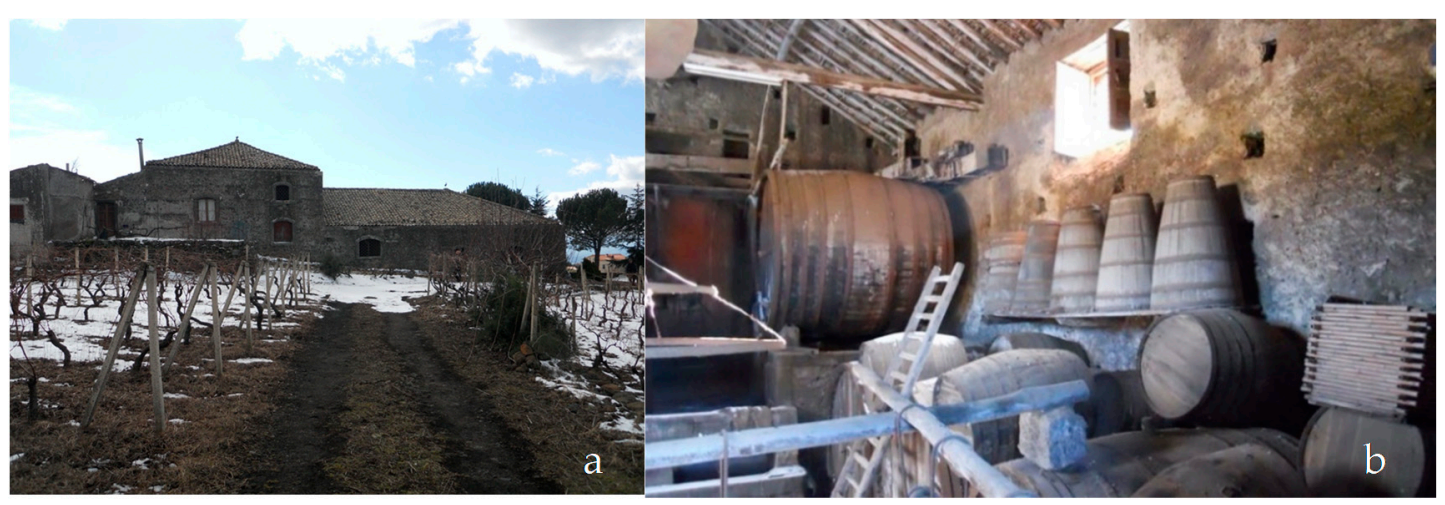

Figure 1. (a) The north façade of the wine cellar; (b) internal room of the wine cellar.

This building is undoubtedly representative of the rural building stock of that area. The main material used for the opaque envelope consists of rough-hewn stones obtained from remote lava fields of the Etna volcano, arranged with a lime mortar. This construction technique was very widespread in the Etna volcano area up until the end of the 1950s, and it is still quite common due to the great availability of volcanic rock. The exterior side of the wall is covered with a thick layer of lime-based plaster and its aggregate a volcanic sand derived from Etna activity, which is a local construction tradition. Lava stone masonry provides high thermal inertia, which is particularly suitable for the climate in this area; indeed, the summer season is quite long and hot, with peak daily outdoor temperatures that may easily exceed $35^{\circ} \mathrm{C}$. The thickness of the walls ranges from 60 to $80 \mathrm{~cm}$.

Thermal transmittance of the walls was measured by using a heat flux meter. The heat flow plate and the external temperature probes were applied on a north-facing wall to avoid direct solar radiation. In agreement with standard ISO 9869, measurement time was chosen equal to three days (from 13 December until 16 December 2017). A value of thermal transmittance equal to $1.780 \mathrm{~W} / \mathrm{m}^{2} \mathrm{~K}$ was measured.

As a result of the transmittance measurement of the walls and their stratigraphy known by endoscopic inspections, the thermal conductivity of basalt stone with mortar was acquired by means of an inverse analytical expression for the calculation of U-values according to ISO 6946. The values of density and specific heat used to characterize the layers of the walls were acquired by ISO 10351.

Table 1 reports the thermophysical properties of the external walls for the building in its current configuration.

Table 1. Thermophysical properties of the external walls for the building in its current configuration.

\begin{tabular}{cccccc}
\hline Layers (from Inside to Outside) & $\mathbf{s}(\mathbf{m})$ & $\lambda(\mathbf{W} / \mathbf{m} \cdot \mathbf{K})$ & $\boldsymbol{\rho} \mathbf{( \mathbf { k g } / \mathbf { m } ^ { 3 } )}$ & $\left.\mathbf{C}_{\mathbf{p}} \mathbf{( J / k g} \cdot \mathbf{K}\right)$ & $\mathbf{R}\left(\mathbf{m}^{\mathbf{2}} \cdot \mathbf{K} / \mathbf{W}\right)$ \\
\hline Internal surface resistance & - & - & - & - & 0.13 \\
Basalt stone with mortar & 0.78 & 2.47 & 2550 & 1000 & 0.32 \\
Plaster (lime) & 0.02 & 0.80 & 1600 & 1000 & 0.025 \\
External surface resistance & - & - & - & - & 0.04 \\
\hline
\end{tabular}

The building is also characterized by a traditional wooden pitched roof constructed as follows (from bottom to up): a double system of beams (main beams and rafters), an intertwined canes mat, and the typical terracotta roof tiles. This type of roof shows a U-value around $1.477 \mathrm{~W} / \mathrm{m}^{2} \cdot \mathrm{K}$.

The windows are single-glazed and with wooden frames $\left(\mathrm{U}=4.82 \mathrm{~W} / \mathrm{m}^{2} \cdot \mathrm{K}\right)$. The solid ground floor of the wine storage room is unpaved, and it consists of a tamped earth floor (made of a mixture of clay, gravel, and sand), laid over the top of a subfloor composed of a crawl space.

Generally, for a traditional tamped earth floor, the topsoil (with organic matter) is removed and filled up with a well compacted inorganic soil (composed of a mixture of clay, sand, gravel). More specifically, a $10 \mathrm{~cm}$-thick barrier layer of clay-rich soil is first applied to a plane level and compacted. Then, a $20-25 \mathrm{~cm}$ layer of coarse to medium gravel is added, which acts as a capillary break. 
Finally, $20 \mathrm{~cm}$ of tamped earth is compacted in layers approximately $6-7 \mathrm{~cm}$ thick. The consistency of the tamped earth material at the time of installation is semisolid to rigid. Each layer is thoroughly compacted and left to dry before the next layer is added. After leveling and compaction, the earth screed, which is the last layer, is additionally tamped with a flat board to tighten the "grain-on-grain" structure. After that, pore water is released, and the surface gathers a shiny appearance with improved mechanical strength.

In the crushing and primary (alcoholic) fermentation room, the ground floor is composed of the crawl space and the earthen layer and finished with lava stone slabs.

The superficial mass (SM) of the building components was calculated using the density values drawn from ISO 10351 and literature. The thermal transmittance of the roof, ground floor, and windows were calculated according to ISO 6946, and values of thermal conductivity acquired by ISO 10351 were used for each layer.

In Table 2, the values of Superficial Mass (SM) and thermal transmittance of the envelope (U) components are reported together with the threshold thermal transmittance of the envelope $\left(\mathrm{U}_{\mathrm{lim}}\right)$ necessary to ensure compliance with Italian regulation [34].

Table 2. Thermal transmittance and surface density of the building components.

\begin{tabular}{cccc}
\hline Building Components & $\mathbf{S M ~}\left(\mathbf{k g} / \mathbf{m}^{2}\right)$ & $\mathbf{U}\left(\mathbf{W} / \mathbf{m}^{2} \cdot \mathbf{K}\right)$ & $\mathbf{U l}_{\mathbf{i m}}\left(\mathbf{W} / \mathbf{m}^{2} \cdot \mathbf{K}\right)$ \\
\hline External masonry & 2070 & 1.78 & $\geq 0.45$ \\
Pitched roof & 43.8 & 1.47 & $\geq 0.38$ \\
Solid ground floor & 190 & 2.47 & $\geq 0.46$ \\
Windows & - & 4.82 & $\geq 3.20$ \\
\hline
\end{tabular}

SM: Superficial Mass (SM); Thermal transmittance of the envelope $\left(\mathrm{U}_{\lim }\right)$.

\subsection{Building Modeling}

The dynamic software Design Builder (Version 6.0, Design Builder Software Ltd., Stroud, UK), a well-known tool based on the calculation engine of Energy Plus, was used to create a model of the real building. The simulations were performed in free-running conditions (without HVAC system), referring only to the building used for the wine cellar (Figure 2), while all other adjacent rooms were considered as adiabatic zones.

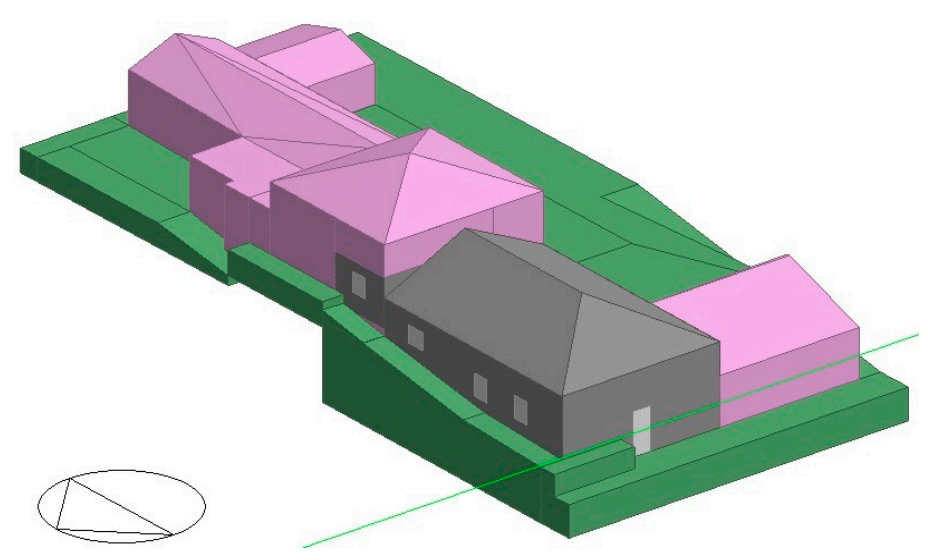

Figure 2. Design Builder Model of the wine cellar (gray).

According to the measured thermal transmittance value (U-value equal to $1.477 \mathrm{~W} / \mathrm{m}^{2} \mathrm{~K}$ ) and to the endoscopic inspections, the wall's stratigraphy was built using the software. Moreover, according to the literature [31,35], the ventilation rate was set equal to $1.5 \mathrm{~h}^{-1}$ considering the air leakage within the building. 
The model was simulated using the 2017 hourly weather data collected by a meteorological station located in Santa Maria di Licodia. Files acquired by weather stations of Sicilian Agrometeorological Information Service were used as input. The model was calibrated using the results of temperature measurements inside the wine cellar.

As a validation of the building model, the profile of indoor air temperature from the DesignBuilder simulation and that measured inside the wine cellar were compared. Figure 3 depicts the profiles of model simulation indoor air temperature plotted against those observed during the period 27 January-5 February 2017.

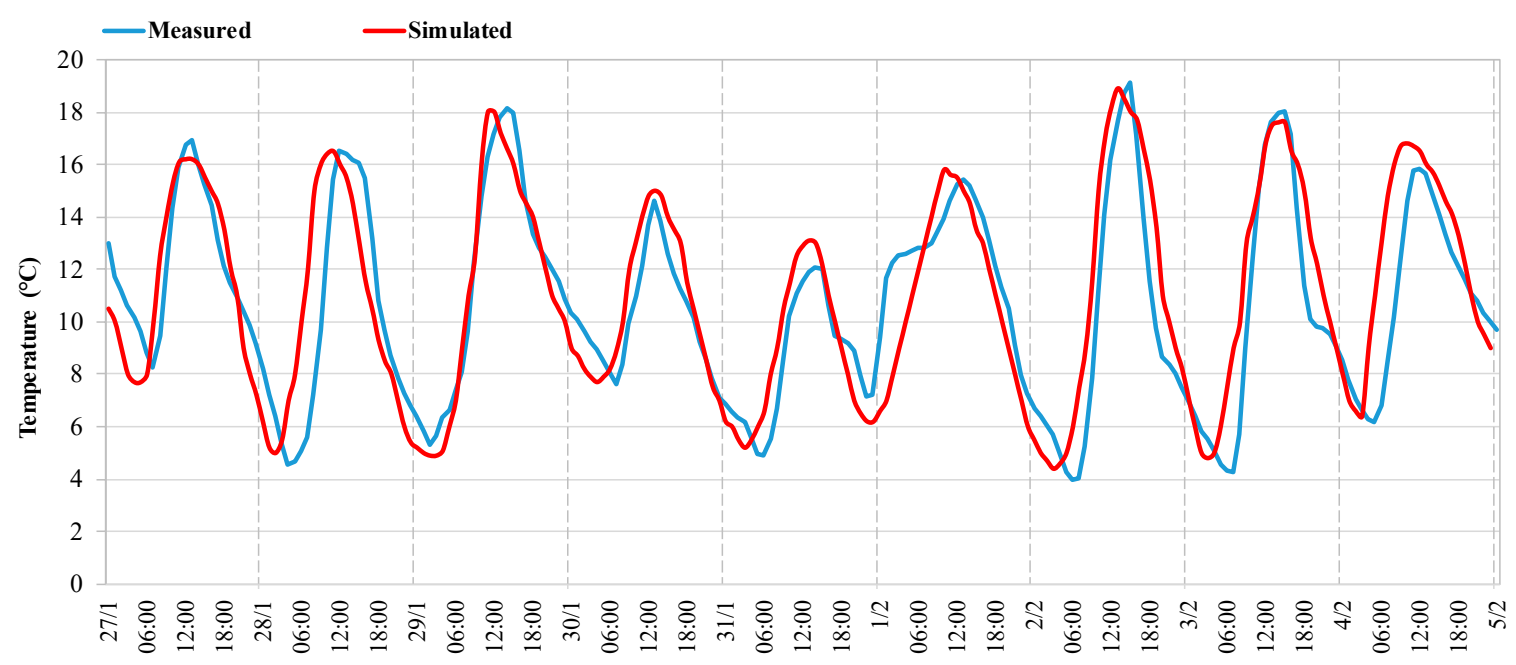

Figure 3. Trend of measured and the model-predicted indoor air temperatures.

The simulated air temperature values have the same trend as that measured. They fit well not only on the maximum values but also on the minimum values. The good reliability and agreement of the simulated values are confirmed by the calculation of statistical indexes (MAE, MBE, CVRSME). Indeed, the value of the coefficient of determination $\left(R^{2}\right)$ is equal to 0.90 , while the value of the Pearson coefficient $(r)$ is equal to 0.86 . In addition, an index of agreement $(d)$ equal to 0.92 approaching unity reveals that the simulation model can be considered reliable enough for analysis of the thermal performance of retrofit strategies based on dynamic simulations. Table 3 summarizes the values of the statistical indexes calculated for the validation model.

Table 3. Statistical indexes used to validate the building simulation model.

\begin{tabular}{ccccccc}
\hline Variables & $\operatorname{MAE}\left({ }^{\circ} \mathbf{C}\right)$ & MBE (\%) & CVRSME (\%) & $r(-)$ & $R^{2}(-)$ & $d(-)$ \\
\hline Indoor temperature & 1.53 & 4.8 & 6 & 0.86 & 0.90 & 0.92 \\
\hline
\end{tabular}

The Mean Absolute Error (MAE); Mean Bias Error (MBE); Coefficient of Variation of the Root Mean Squared Error (CVRMSE).

\subsection{Retrofit Strategies}

In order to carry out the upgrading of the building envelope to comply with the Italian legislation, some possible interventions [36-38] are contemplated, not only considering the energetic retrofitting requirement of the rural house, but especially the thermal behavior of the unconditioned space like the wineries and wine cellars. 
The retrofit strategies essentially consist of:

- application of thermal insulation on the inner surface of the external walls so that the façade is not disturbed by any intervention, with the aim of not interfering with the architectural attractiveness of this traditional building;

- replacement of existing wooden roof stratigraphy with an insulated roof with a new wooden loadbearing structure;

- realization of an insulated solid ground floor;

- replacement of windows components while keeping the chestnut wood as frame material.

The intervention on the external vertical closures is based on the installation of a $4 \mathrm{~cm}$ panel of Aeropan $\left(\lambda=0.015 \mathrm{~W} / \mathrm{m} \mathrm{K}, \mathrm{c}_{\mathrm{p}}=1000 \mathrm{~J} / \mathrm{kg} \mathrm{K}, \rho=230 \mathrm{~kg} / \mathrm{m}^{3}\right)$ on the inner side of all masonries. Aeropan consists of a nanotechnological insulation in Aerogel coupled with a polypropylene breathing membrane reinforced with glass fiber. Concerning the roof upgrade, a $10 \mathrm{~cm}$ insulation layer of hemp fiber panel $\left(\lambda=0.038 \mathrm{~W} / \mathrm{m} \mathrm{K}, c_{p}=1700 \mathrm{~J} / \mathrm{kg} \mathrm{K}, \rho=30 \mathrm{~kg} / \mathrm{m}^{3}\right)$ is placed on the wooden planks, upon a vapor barrier; the insulation is protected from the top by a waterproofing membrane. The upper part of the roof is completed by wooden laths, which define an unventilated air gap upwards of $8 \mathrm{~cm}$.

The solid ground floor, simply consisting of a tamped earth layer on a crawl space subfloor, is replaced by a "modern" tamped earth floor. In order to ensure a better distribution of loads for buildings in seismic areas and to avoid cracks in the clay floor, a concrete screed with electrowelded mesh was inserted.

Therefore, starting from the original layer of sand and gravel, in the new solid ground floor there are, in order from bottom to top: a layer of expanded clay granules, a layer of granulated foamglass, a concrete screed reinforced with electrowelded mesh, and a tamped earth floor. Generally, the earth floor is finished with four to six coats of oil, often hemp or linseed, then topped with a combination of soft waxes. This treatment provides sheen and waterproofing to the floor. In our study, we propose not to complete this finishing to facilitate breathability.

This earthen floor allows regulation of the relative air humidity because clay absorbs water vapor when the air is too wet, whereas it is able to release water vapor when the air is drier. As some authors pointed out [39], the physical behavior of raw earth layers is typical of massive porous materials where coupled hygrothermal mechanisms coexist inside the micropore network geometry; in this case, the pavement experiences a heat transmission mechanism for materials with a high thermal mass, with consequent high thermal inertia and heat storage, evaporation, and condensation inside the pores, resulting from temperature changes produced by thermal waves. An absorption/release of moisture contained in the pores occurs because of the change in ambient humidity and the influence of rising dampness [40].

Due to their density and high thermal conductivity, dry earth floors are thermally efficient, capable of absorbing heat and releasing it gradually over time-the thermal "flywheel" effect. The English Heritage, in its guidance note titled, Energy Efficiency and Historic Buildings: Insulating Solid Ground Floors, observes that "the ground itself maintains a surprisingly stable temperature of around $10{ }^{\circ} \mathrm{C}^{\prime \prime}$ [41]. The intervention on the external windows consists in the replacement of the current single glazing with double glazing $(\mathrm{s}=4 \mathrm{~mm})$ separated by an air gap $(\mathrm{s}=16 \mathrm{~mm})$ with a chestnut wood frame. A low emissivity coating $(\varepsilon=0.10)$ on the inner glazing is proposed. Ventilation rate is set equal to $0.5 \mathrm{ac} / \mathrm{h}$.

The thermophysical properties of each layer that composes the building construction after retrofit interventions are reported in Table 4. 
Table 4. Thermophysical properties for each layer that composes opaque and glazing components after retrofit.

\begin{tabular}{|c|c|c|c|c|}
\hline \multicolumn{5}{|c|}{ a) Wall } \\
\hline Layer & $\mathrm{s}(\mathrm{m})$ & $\lambda(\mathrm{W} / \mathrm{m} \cdot \mathrm{K})$ & $\rho(\mathrm{kg} / \mathrm{m} 3)$ & $\mathrm{Cp}(\mathrm{J} / \mathrm{kg} \cdot \mathrm{K})$ \\
\hline Basalt stone with mortar & 0.78 & 2.47 & 2550 & 1000 \\
\hline Lime mortar & 0.01 & 0.900 & 1800 & 1000 \\
\hline Aeropan & 0.04 & 0.015 & 230 & 1000 \\
\hline Lime mortar & 0.01 & 0.419 & 1800 & 1000 \\
\hline Inner plaster (lime + gypsum) & 0.02 & 0.80 & 1600 & 1000 \\
\hline \multicolumn{5}{|c|}{ b) Ground Floor } \\
\hline Layer & $\mathrm{s}(\mathrm{m})$ & $\lambda(\mathrm{W} / \mathrm{m} \cdot \mathrm{K})$ & $\rho(\mathrm{kg} / \mathrm{m} 3)$ & $\mathrm{Cp}(\mathrm{J} / \mathrm{kg} \cdot \mathrm{K})$ \\
\hline Raw earth ground & 0.03 & 0.80 & 2000 & 1000 \\
\hline Concrete screed & 0.10 & 1.160 & 2000 & 1000 \\
\hline Granulated foamglass & 0.04 & 0.045 & 125 & 900 \\
\hline Expanded clay granules & 0.10 & 0.120 & 280 & 920 \\
\hline Sand and gravel & 0.20 & 1.200 & 1700 & 1000 \\
\hline \multicolumn{5}{|c|}{ c) Roof } \\
\hline Layer & $\mathrm{s}(\mathrm{m})$ & $\lambda(\mathrm{W} / \mathrm{m} \cdot \mathrm{K})$ & $\rho(\mathrm{kg} / \mathrm{m} 3)$ & $\mathrm{Cp}(\mathrm{J} / \mathrm{kg} \cdot \mathrm{K})$ \\
\hline Wooden Plank & 0.03 & 0.15 & 450 & 1600 \\
\hline Vapor barrier & 0.0002 & 0.130 & 950 & 1800 \\
\hline Hemp panel & 0.09 & 0.038 & 30 & 1700 \\
\hline Waterproofing membrane & 0.009 & 0.17 & 52.50 & 1800 \\
\hline Air gap & 0.08 & & - & \\
\hline Terracotta tiles & 0.02 & 1.000 & 2000 & 840 \\
\hline
\end{tabular}

The values of superficial mass and thermal transmittance of each opaque envelope component after RIs (retrofitting interventions) are reported in Table 5. It also shows the limit U-values $\left(\mathrm{U}_{\text {lim }}\right)$ that the same building components have to comply with the Italian regulation [34] for the climate zone of Catania. Tables 5 and 6 show the thermal transmittance and superficial mass of the building components after retrofit interventions (RIs). Moreover, the comparison between the U-values of the envelope components at the current state and the thermal transmittance of the same components after retrofit interventions (RIs) are reported.

Table 5. Thermal transmittance and surface density of the opaque components.

\begin{tabular}{ccccc}
\hline Building Components & $\mathbf{S M}_{\mathbf{R I}} \mathbf{( k g / \mathbf { m } ^ { 2 } )}$ & $\mathbf{U}_{\mathbf{R I}}\left(\mathbf{W} / \mathbf{m}^{\mathbf{2}} \cdot \mathbf{K}\right)$ & $\mathbf{U}_{\mathbf{L i m}}\left(\mathbf{W} / \mathbf{m}^{2} \cdot \mathbf{K}\right)$ & $\Delta \mathbf{U}=\mathbf{U}-\mathbf{U}_{\mathbf{R I}}\left(\mathbf{W} / \mathbf{m}^{\mathbf{2}} \cdot \mathbf{K}\right)$ \\
\hline External walls & 2070 & 0.315 & $\leq 0.45$ & 1.645 \\
Pitched roof & 59.0 & 0.309 & $\leq 0.38$ & 1.168 \\
Solid ground floor & 562 & 0.460 & $\leq 0.46$ & 2.051 \\
\hline
\end{tabular}

Table 6. Main thermophysical properties of the windows.

\begin{tabular}{cccc}
\hline \multirow{2}{*}{ Property } & \multirow{2}{*}{ Unit } & \multicolumn{2}{c}{ Value } \\
\cline { 3 - 4 } & & Before & After \\
\hline Emissivity of the glazed surface & - & 0.84 & 0.10 \\
Glass g-value & $\mathrm{W} / \mathrm{m}^{2} \cdot \mathrm{K}$ & 5.88 & 0.75 \\
Thermal transmittance of the glazing & $\mathrm{W} / \mathrm{m}^{2} \cdot \mathrm{K}$ & 3.50 & 2.00 \\
Thermal transmittance of the frame & $\mathrm{W} / \mathrm{m}^{2} \cdot \mathrm{K}$ & 4.82 & 2.70 \\
\hline
\end{tabular}


It can be observed that the proposed solutions for the building upgrading have lower thermal transmittance values than the ones imposed by current Italian regulations. It has to be highlighted that this choice results in a significant thickness of the insulation layer or in the use of very performative materials in the upgraded building components for satisfying the limit U-values. The results of the simulations will demonstrate the appropriateness of this choice.

\section{Results}

\subsection{The Building in its Current State}

The results of the free-running performance for the current building are shown in Figures 4 and 5 . In Figure 4, the simulated hourly profile of the outdoor temperature $\left(T_{0}\right)$, the measured indoor air temperature $\left(\mathrm{T}_{\mathrm{am}}\right)$, and the simulated indoor air temperature $\left(\mathrm{T}_{\mathrm{as}}\right)$ can be observed for a representative week in winter. There is good agreement between the measured and simulated values. The measured indoor air temperature ranges from a minimum of $10.4{ }^{\circ} \mathrm{C}$ to a maximum of $15.5^{\circ} \mathrm{C}$, and a mean daily oscillation of $4.1^{\circ} \mathrm{C}$ is achieved during the period 27 January-5 February. The relative humidity presents a mean value of $71 \%$, which is suitable for the storage of wine.

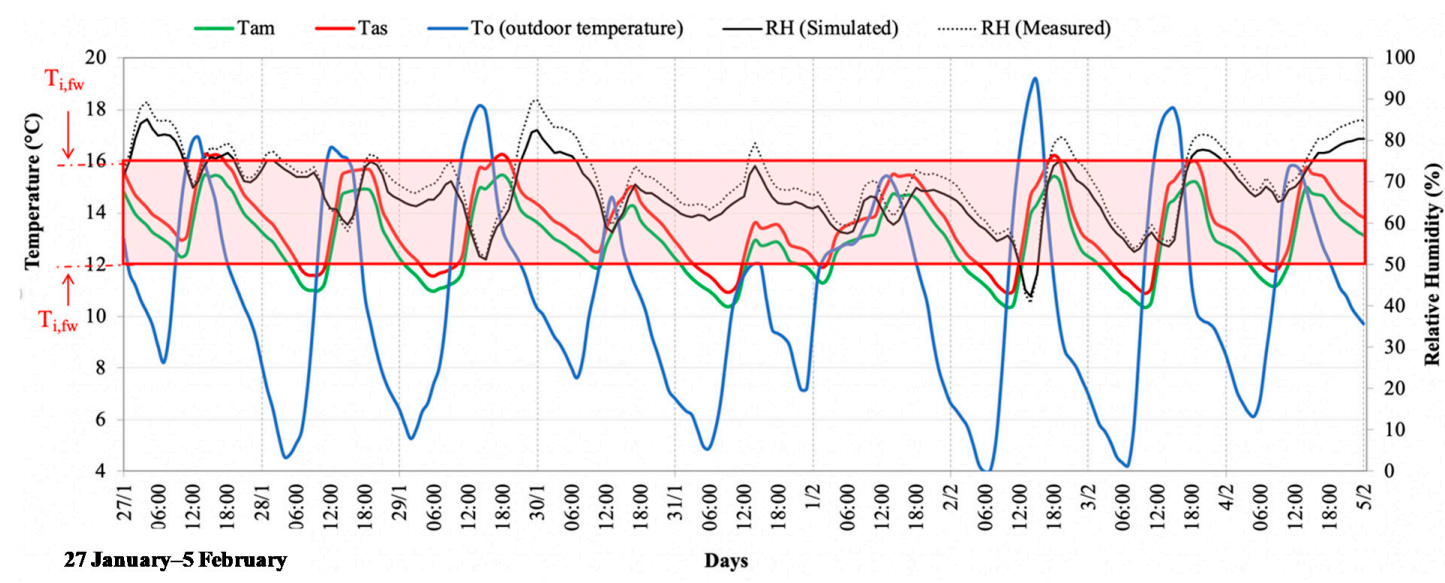

Figure 4. Daily profile of indoor temperatures at the current state of the building in free-running conditions during 27 January-5 February.

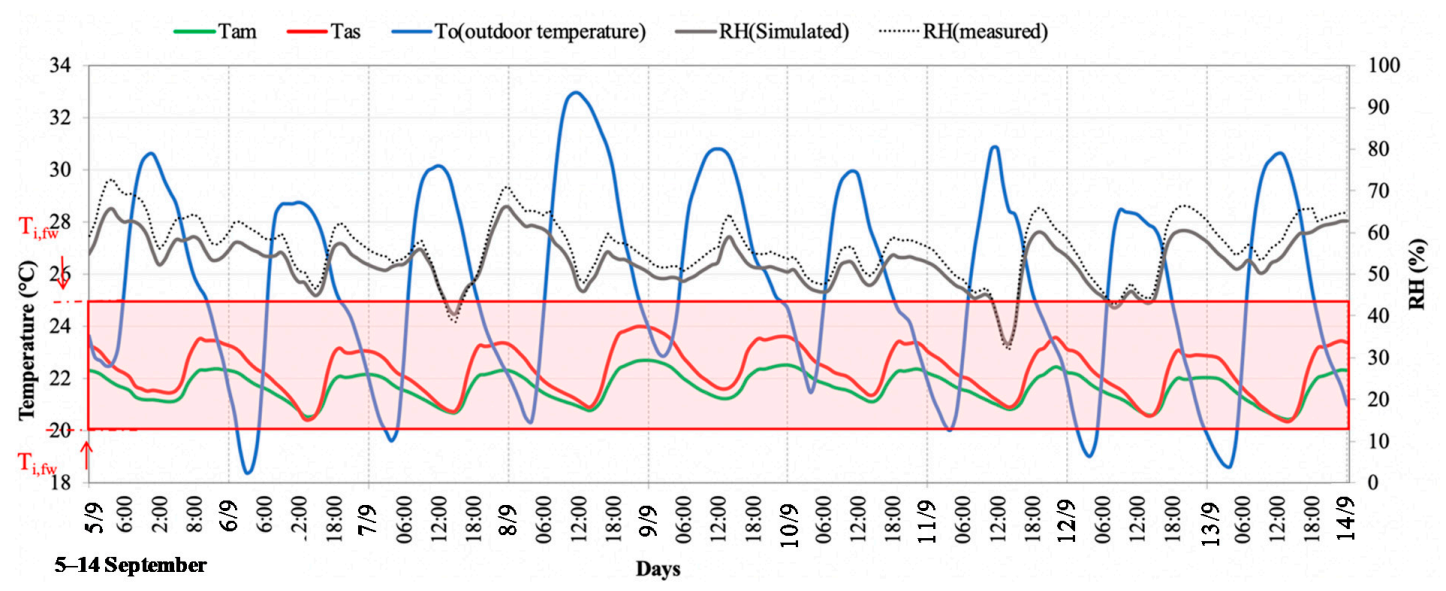

Figure 5. Daily profile of indoor temperatures at the current state of the building in free-running conditions during 5-14 September.

The trend of simulated temperature ranges from a minimum of $10.9^{\circ} \mathrm{C}$ to a maximum of $16.3^{\circ} \mathrm{C}$ and a mean daily oscillation of $5.3^{\circ} \mathrm{C}$, while the mean value of humidity is $68.8 \%$ and not congruent with the measured value. 
The minimum values of $\mathrm{T}_{\mathrm{am}}$ usually occur at 6:00 a.m. and its peak values are at around 3:00 p.m. The values of indoor temperature testify a good behavior of the building for aging and storage of the wine in wooden barrels during the winter period, considering that the range of optimal temperature is from 12 to $16^{\circ} \mathrm{C}$. Figure 5 depicts the simulated hourly trend of indoor thermal conditions during period (5-14 September).

The profile of measured indoor air temperature shows a minimum value of $20.4^{\circ} \mathrm{C}$ and a maximum of $22.7^{\circ} \mathrm{C}$. Mean daily amplitude of air temperature wave of $3.0^{\circ} \mathrm{C}$ is obtained.

In summer, the simulated air temperatures values are in good agreement with the measured ones, oscillating only between 20.3 and $24.0^{\circ} \mathrm{C}$. The mean value of humidity measured is $53.5 \%$ and is very close to the one simulated (57.0\%).

The minimum values of $\mathrm{T}_{\mathrm{am}}$ occur at around 5:00 a.m., whereas its maximum values are at 1:00 p.m. according to the profile of outdoor air temperature. It has to be highlighted that the values of air temperature are suitable for the alcoholic fermentation of wine because the variation of temperature of air is included in the range of $20-25^{\circ} \mathrm{C}$.

Some peculiarities regarding the constructive technology of our case study-like the lava stone masonry and the crawl space in the solid ground floor-make our results not immediately comparable with previous literature. The previous literature review evidence shows that there are few studies about the indoor thermal behavior of the wine cellars with a massive structure that, together with differences in terms of orientation, morphological characteristics, and climate conditions, make a useful comparison difficult.

\subsection{Expected Results after Thermophysical Upgrading}

The thermal behavior of the building after the upgrading is shown in order to evaluate the potentiality of the interventions on the performance of storage and fermentation of wine. In this scenario, all proposed abovementioned technological solutions for building retrofitting are implemented.

For this purpose, Figures 6 and 7 show the results of the simulations with the application of the retrofit solutions for two representative periods: 27 January-5 February and 5-14 September.

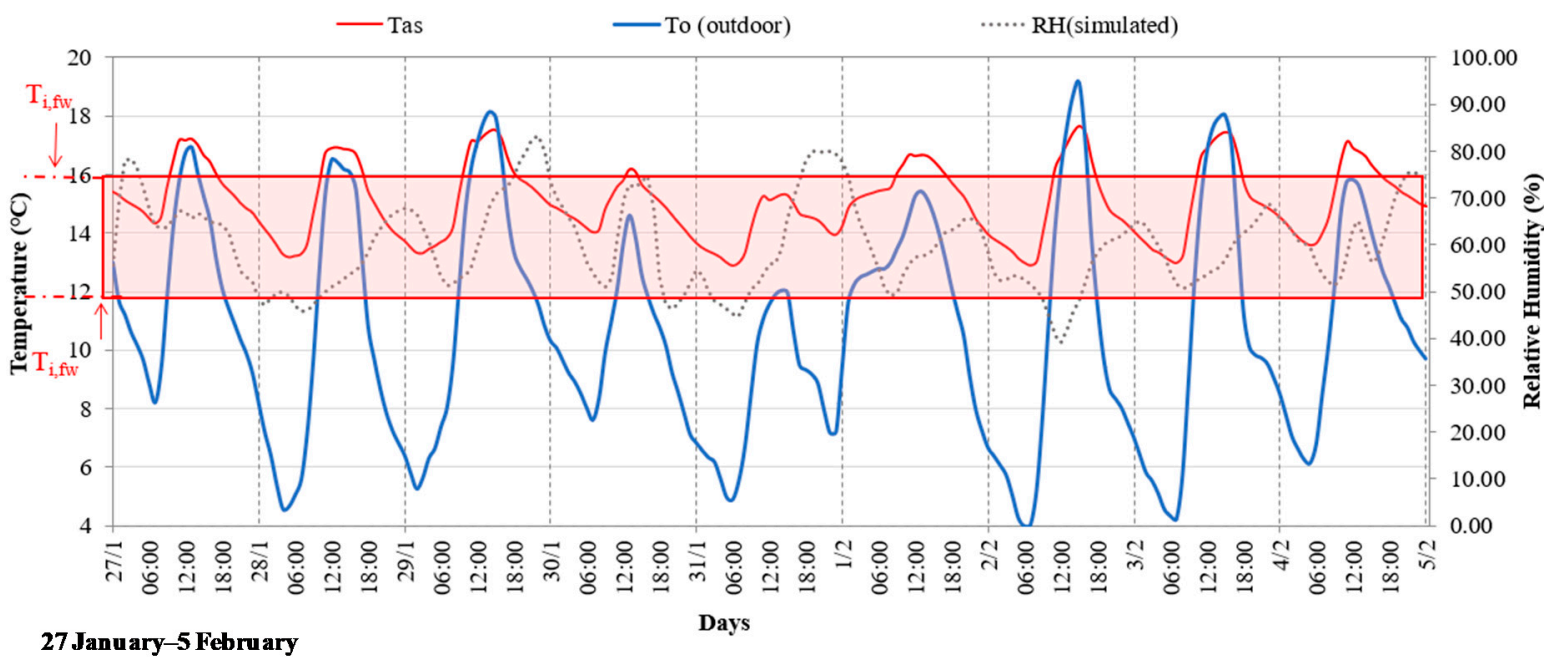

Figure 6. Daily profile of indoor air and operative temperature after retrofit of the building in free-running conditions during 27 January-5 February. 


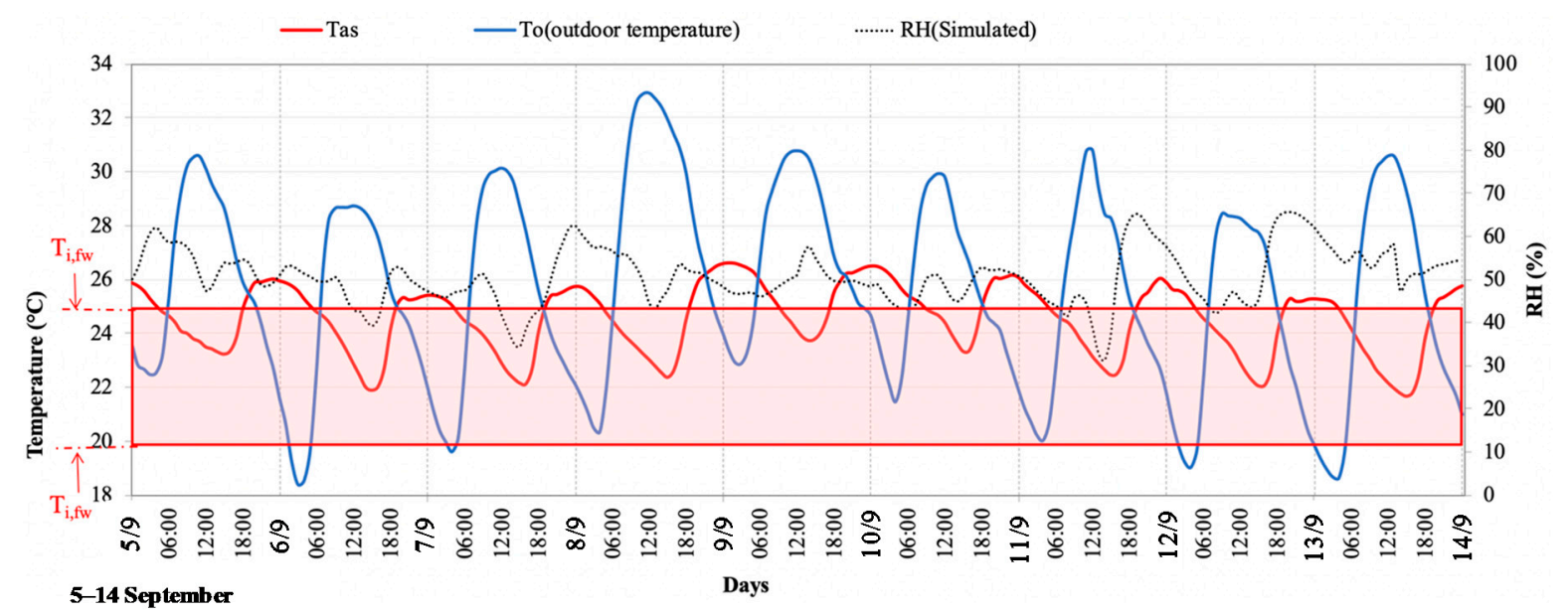

Figure 7. Daily profile of air and operative temperature after retrofit of the building in free-running conditions during 5-14 September.

Figure 6 shows that the hourly profile of air temperature ranges between $12.9-17.7^{\circ} \mathrm{C}$ and maximum amplitude of temperature curve about $4.8^{\circ} \mathrm{C}$. As a consequence, the indoor thermal state continues to guarantee adequate conditions for the storage of the wine in the barrels for most of the investigated period, but the peak values of temperature are always above the upper optimal values.

During the summer period, the indoor temperature is up to the optimal limit due to the application of the insulation and the replacement of windows with an improvement of air tightness. Indeed, the profile of temperature of air ranges from $21.7^{\circ} \mathrm{C}$ to $26.6^{\circ} \mathrm{C}$ with a maximum daily amplitude of wave about $5.0^{\circ} \mathrm{C}$. As a result, it can be observed that the average indoor temperature $\left(25.1^{\circ} \mathrm{C}\right)$ is higher than the maximum value of temperature for a correct fermentation of wine. The relative humidity assumes a mean value of $53.8 \%$.

According to these results, the indoor thermal behavior of the retrofit scenario (RI) is worse than the building's current state in summer conditions, if alcoholic fermentation and store process of wine are considered.

\subsection{Potential Effects of Insulated Floor on Ground Surface}

Comparing the thermal performance of the wine cellar at the current state (TR) and after its retrofit scenario (RI), it is evident that the implementation of standard energy efficient measures, applied to a bioclimatic structure, leads to a worst thermal behavior due, basically, to the insulation of the pavement that plays a fundamental role in heat and mass exchange for the maintenance of suitable temperature for wine storage and aging. This latter behavior is noticeable in Figures 8 and 9 , where the temperature and humidity trend with (RI) are reported, and without thermal floor insulation (RI-IGF) and in current state (TR). In addition, in Table 7, the maximum and minimum values of air temperature, the maximum amplitude of temperature $\left(\Delta \mathrm{T}_{\mathrm{a}, \max }\right)$, and the average value of relative humidity $(\mathrm{RH})$ related to the three scenarios mentioned during the period 27 January- 5 February are reported. In Table 8, the maximum and minimum values of air temperature, the maximum amplitude of temperature, and the average value of humidity related to the three scenarios mentioned during period 5-14 September are reported. 


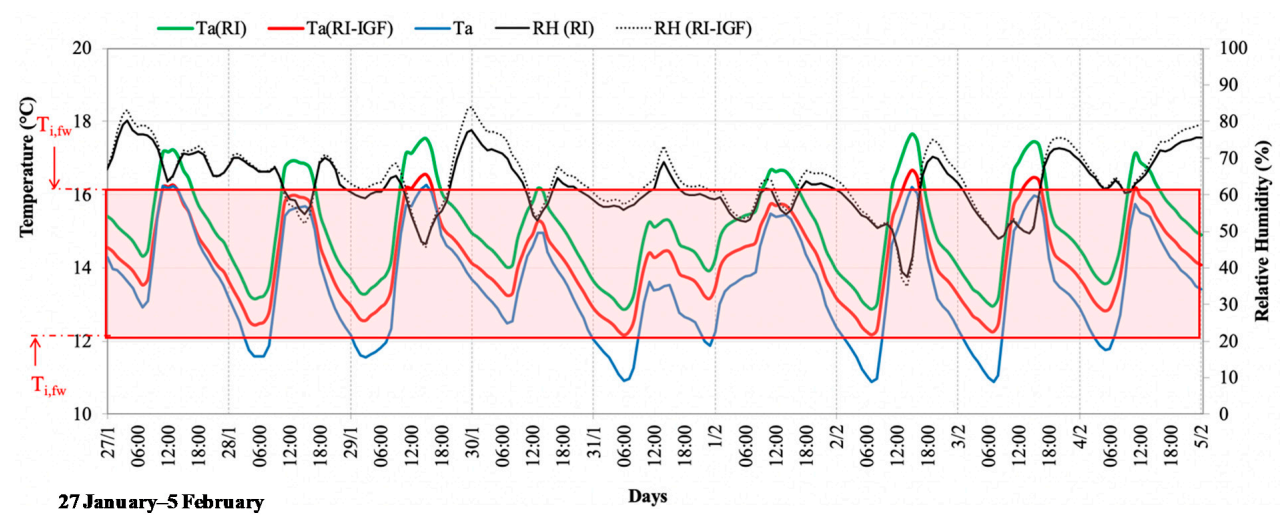

Figure 8. Daily profile of air temperature $\left(\mathrm{T}_{\mathrm{a}}\right)$ in the current state, after retrofit $\mathrm{Ta}(\mathrm{RI})$, and retrofit scenario with uninsulated floor on ground surface (RI-IGF) during the period 27 January-5 February.

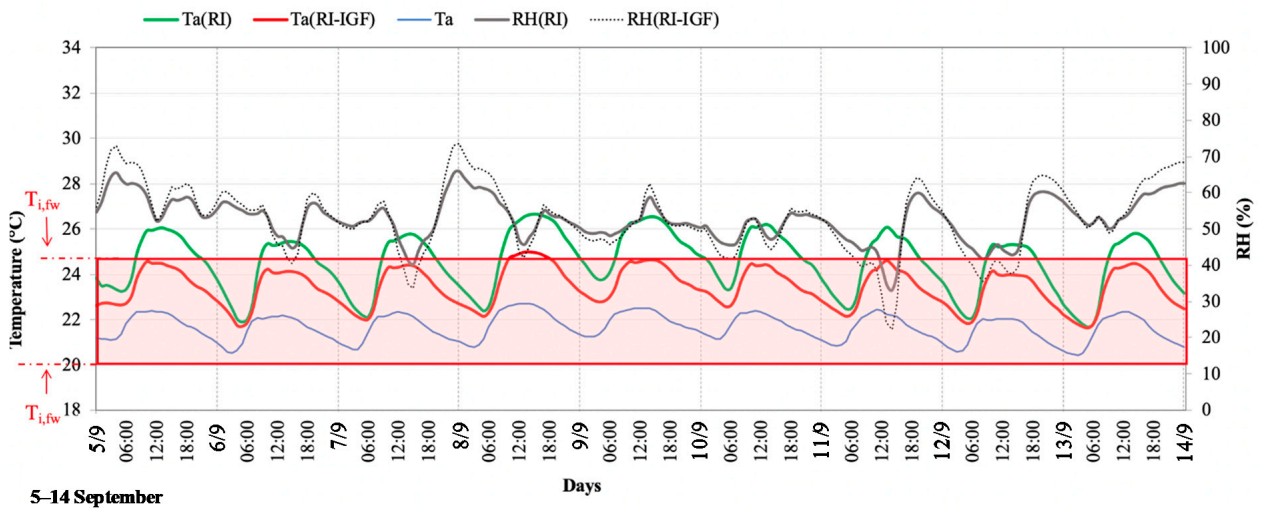

Figure 9. Daily profile of air temperature $\left(\mathrm{T}_{\mathrm{a}}\right)$ in the current state, after retrofit $\mathrm{Ta}(\mathrm{RI})$, and retrofit scenario with no insulated floor on ground surface (RI-IGF) during the period 5-14 September.

Table 7. Maximum and minimum values of air temperature, maximum amplitude of temperature, and relative humidity of the three investigated scenarios during period 27 January -5 February.

\begin{tabular}{cccccc}
\hline Scenario & & $\begin{array}{c}\mathbf{T}_{\mathbf{a}, \max } \\
\left({ }^{\circ} \mathbf{C}\right)\end{array}$ & $\begin{array}{c}\mathbf{T}_{\mathbf{a}, \min } \\
\left({ }^{\prime} \mathbf{C}\right)\end{array}$ & $\begin{array}{c}\Delta \mathbf{T}_{\mathbf{a}, \max } \\
\left({ }^{\circ} \mathbf{C}\right)\end{array}$ & $\mathbf{R H} \%$ \\
\hline $\begin{array}{c}\text { Current state } \\
\text { After retrofit }\end{array}$ & TR & 16.3 & 10.9 & 5.4 & 71.0 \\
$\begin{array}{c}\text { After retrofit with no } \\
\text { insulation on ground floor }\end{array}$ & RI-IGF & 17.7 & 12.9 & 4.8 & 63.7 \\
\hline
\end{tabular}

Table 8. Maximum and minimum values of air temperature, maximum amplitude of temperature, and relative humidity of the three investigated scenarios during the period 5-14 September.

\begin{tabular}{cccccc}
\hline Scenario & & $\begin{array}{c}\mathbf{T}_{\mathbf{a}, \max } \\
\left({ }^{\circ} \mathbf{C}\right)\end{array}$ & $\begin{array}{c}\mathbf{T}_{\mathbf{a}, \min } \\
\left({ }^{\circ} \mathbf{C}\right)\end{array}$ & $\begin{array}{c}\Delta \mathbf{T}_{\mathbf{a}, \max } \\
\left({ }^{\circ} \mathbf{C}\right)\end{array}$ & $\mathbf{R H} \%$ \\
\hline $\begin{array}{c}\text { Current state } \\
\text { After retrofit }\end{array}$ & TR & 22.7 & 20.4 & 2.3 & 57.0 \\
$\begin{array}{c}\text { After retrofit with no } \\
\text { insulation on ground floor }\end{array}$ & RI-IGF & 26.6 & 21.7 & 4.9 & 53.8 \\
\hline
\end{tabular}

Indeed, looking at the results, it is worth noticing that, in winter, the minimum and maximum values of temperatures rise, but the optimal value of temperature for wine storage and aging is still guaranteed. Basically, only the humidity undergoes a decrement from ideal values. However, the peaks of temperature (RI) exceed the upper limit of $16^{\circ} \mathrm{C}$ by about $1.7^{\circ} \mathrm{C}$. The latter value is lower in the 
RI-IGF scenario configuration by around $0.7^{\circ} \mathrm{C}$. In any case, the insulation of the building leads to a reduction of oscillation between the peak values of temperature as reported in Table 7 .

In summer, the thermal insulation applied leads to the overheating of the building and to the increment of indoor temperatures beyond the optimal values as reported in Figure 9. Indeed, the peak of maximum temperature is $26.6^{\circ} \mathrm{C}$ in the RI scenario, on the other hand, although the increment of temperature occurs also in RI-IGF, the peaks lie within the ideal values (Table 8). On the contrary, the mean values of humidity do not undergo substantial variation compared to the current state.

The outcomes about the effectiveness of retrofitting scenarios on the indoor thermal conditions of the wine cellar are not comparable with those of other studies. In literature, there are a few studies [17] that deal only with the evaluation of indoor thermal conditions of traditional wine cellars in their current configurations. Poor attention is given to the thermal and physical properties of the materials used in the building components (such as the lava stone masonry and the crawl space solid ground floor) and in their retrofitted configurations. Finally, dynamic and energetic thermal simulations have rarely been used for the analysis of thermal performance of farm winery buildings.

\section{Conclusions}

The current research focused on the importance of traditional construction knowledge based on the use of locally sourced natural base materials and bioclimatic design choices, as those used for rural buildings in Etna volcano area. These dwellings are usually single or double-story buildings, resting on the slope of the site and using local building materials, such as lava stone. Lava stone is renowned for its use in masonry for the realization of thick walls, ranging from 60 to $80 \mathrm{~cm}$, providing high thermal inertia, which is particularly important in Mediterranean climates. A good bioclimatic approach is always detectable in these buildings, as a result of the adaptation to natural phenomena that could contribute in creating better living spaces concerning sunlighting, exposure, and ventilation aspects.

This kind of traditional architecture was often used in farm wineries and wine cellars, productive spaces where typical temperature and humidity conditions must be maintained almost constant in order to allow an optimal wine fermentation, aging, and storing process.

This study therefore analyzed the effectiveness of a wine cellar located in the Mount Etna area, concerning its efficiency in maintaining adequate thermal and humidity indoor conditions for wine production. In this sense, the U-value measurements made onsite have allowed a certain level of accuracy for the Design Builder model, which was implemented in order to compare the current state of the building with different retrofit strategies. Temperature and humidity values of the current state simulation were calibrated with measurements made onsite, confirming the correctness of the model.

The observation of measured and simulated current state temperature and humidity showed an interesting adjustment within the limits considered to be optimal for wine production (including fermentation, aging, and storage processes). Nevertheless, the simulation highlighted that some usual retrofit interventions made to comply with the Italian energy saving regulation, such as the insulation of all elements of the envelope (roof, walls, and solid ground floor) and the replacement of the windows, cause an increase in average indoor temperatures during summer, affecting the process of alcoholic fermentation and storage of wine.

For this reason, a corrected retrofit scenario was investigated, where walls and roof are insulated whereas the ground insulation is not. This is because the existing earth floor, due to its density and high thermal conductivity, is particularly capable of absorbing heat and releasing it gradually over time (thermal "flywheel" effect). Therefore, the heat and mass exchange through the solid ground floor is not modified, with good consequences in the global thermal behavior of the building. In this scenario, indoor temperatures in summer conditions are higher than the current state ones, but they fall within the limits for the wine cellar activity, while humidity values remain closer to the optimal ones for aging of wine. 
This paper showed the importance of contrasting usual upgrading and retrofit strategies for existing buildings, with the ones that are possible to apply to vernacular dwellings designed with a bioclimatic approach. In order to assess the best retrofitting options, several calibrated dynamic thermal simulations were run on Design Builder software, referring to the most extreme hygrothermal conditions during a year, and allowing a considerable reduction in data collection compared to previously used methodologies. The specificity of some traditional constructive practices (as the use of massive and uninsulated solid ground floors and walls), makes wine cellars an interesting case study. Because of this specificity, the environmental conditions (indoor temperature and humidity), which must be maintained for optimal fermentation and aging of wine, have to guide the upgrading and retrofit strategies on these buildings, even if this means not to comply with current national energetic regulations.

Author Contributions: Conceptualization, F.N., M.D.; methodology, G.G., R.C., M.D. and F.N.; formal analysis, M.D.; investigation, F.N. and M.D.; resources, G.G. and R.C.; data curation, G.G., R.C., M.D..; writing-original draft preparation, G.G., M.D., R.C. and F.N.; writing-review and editing, G.G., R.C., M.D. and F.N.; visualization, G.G.; supervision, R.C. and F.N.; project administration, G.G., R.C. and F.N.; funding acquisition, F.N. All authors have read and agreed to the published version of the manuscript.

Funding: This research received no external funding.

Conflicts of Interest: The authors declare no conflict of interest.

\section{References}

1. European Parliament. Directive 2002/91/EC of The European Parliament and of the Council of 16 December 2002 on the energy performance of buildings. Official Journal of the European Union. 1 April 2003. Available online: https://eur-lex.europa.eu/ (accessed on 20 June 2020).

2. European Parliament. Directive 2010/31/EU of The European Parliament and of the Council of 19 May 2010 on the energy performance of buildings (recast). Official Journal of the European Union. 18 June 2010. Available online: https://eur-lex.europa.eu/ (accessed on 20 June 2020).

3. Costanzo, V.; Evola, G.; Marletta, L.; Nocera, F. The effectiveness of phase change materials in relation to summer thermal comfort in air-conditioned office buildings. Build. Simul. 2018, 11, 1145-1161. [CrossRef]

4. Nocera, F.; Faro, A.L.; Costanzo, V.; Raciti, C. Daylight performance of classrooms in a Mediterranean school heritage building. Sustainability 2018, 10, 3705. [CrossRef]

5. Trovato, M.R.; Nocera, F.; Giuffrida, S. Life-cycle assessment and monetary measurements for the carbon footprint reduction of public buildings. Sustainability 2020, 12, 3460. [CrossRef]

6. Disciplinare di Produzione dei vini a Denominazione di Origine Controllata "Etna", Gazzetta Ufficiale della Repubblica Italiana, Serie Generale n. 243. 18 October 2011. Available online: https://www.gazzettaufficiale.it (accessed on 20 June 2020).

7. Caltabiano, I. The traditional architecture in Sicily: The rural area around the volcano Etna. In Proceedings of the PLEA 2006, the 23rd Conference on Passive and Low Energy Architecture, Geneva, Switzerland, 6-8 September 2006.

8. Palumbo, G.; Magnano di San Lio, E. Le Residenze di Campagna nel Versante Orientale dell'Etna, Dipartimento di Architettura e Urbanistica; Università degli Studi di Catania: Catania, Italy, 1991.

9. Zhai, Z.J.; Previtali, J.M. Ancient vernacular architecture: Characteristics categorization and energy performance evaluation. Energy Build. 2010, 42, 357-365. [CrossRef]

10. Nguyen, A.-T.; Tran, Q.B.; Tran, D.Q.; Reiter, S. An investigation on climate responsive design strategies of vernacular housing in Vietnam. Build. Environ. 2011, 46, 2088-2106. [CrossRef]

11. Zagorskas, J.; Zavadskas, E.K.; Turskis, Z.; Burinskiene, M.; Blumberga, A.; Blumberga, D. Thermal insulation alternatives of historic brick buildings in Baltic Sea Region. Energy Build. 2014, 78, 35-42. [CrossRef]

12. Cardinale, N.; Rospi, G.; Stazi, A. Energy and microclimatic performance of restored hypogeous buildings in south Italy: The "Sassi" district of Matera. Build. Environ. 2010, 45, 94-106. [CrossRef]

13. Ozay, N. A comparative study of climatically responsive house design at various periods of Northern Cyprus architecture. Build. Environ. 2005, 40, 841-852. [CrossRef] 
14. Khalili, M.; Amindeldar, S. Traditional solutions in low energy buildings of hot-arid regions of Iran. Sustain. Cities Soc. 2014, 13, 171-181. [CrossRef]

15. Giucastro, F.G.S.; Giordano, D. Et(h)nic Architecture in Mediterranean Area. Energy Procedia 2016, 96, 868-880. [CrossRef]

16. Troost, G. Technologie des Weines (Handbuch der Lebensmitteltechnologie), 6th ed.; Ulmer Verlag: Stuttgart, Germany, 1988.

17. Ribéreau-Gayon, P.; Dubourdieu, D.; Donèche, B.; Lonvaud, A. Handbook of Enology; John Wiley and Sons: Chichester, UK, 2006; Volume 1.

18. Mazarrón, F.R.; Cid-Falceto, J.; Cañas, I. Ground Thermal Inertia for Energy Efficient Building Design: A Case Study on Food Industry. Energies 2012, 5, 227-242.

19. Cañas Guerrero, I.; Martin Ocaña, S. Study of the thermal behaviour of traditional wine cellars: The case of the area of "Tierras Sorianas del Cid" (Spain). Renew. Energy 2005, 30, 43-55. [CrossRef]

20. Tassinari, P.; Barbaresi, A.; Benni, S.; Torreggiani, D. Farm wineries design: Preliminary indications for integrating energy efficiency in building modelling. In Proceedings of the International Conference of Agricultural Engineering, Valencia, Spain, 8-12 July 2012.

21. Barbaresi, A.; Dallacasa, F.; Torreggiani, D.; Tassinari, P. Retrofit interventions in non-conditioned rooms: Calibration of an assessment method on a farm winery. J. Build. Perform. Simul. 2017, 10, 91-104. [CrossRef]

22. Tinti, F.; Barbaresi, A.; Benni, S.; Torreggiani, D.; Bruno, R.; Tassinari, P. Experimental analysis of thermal interaction between wine cellar and underground. Energy Build. 2015, 104, 275-286. [CrossRef]

23. Tassinari, P.; Galassi, S.; Benni, S.; Torreggiani, D. The built environment of farm wineries: An analysis methodology for defining meta-design requirements. J. Agric. Eng. 2011, 42, 25-31.

24. Giuffrida, S.; Gagliano, F.; Nocera, F.; Trovato, M.R. Landscape assessment and economic accounting in wind farm programming: Two cases in sicily. Land 2018, 7, 120. [CrossRef]

25. Widera, B. Bioclimatic Architecture as an Opportunity for developing countries. In Proceedings of the 30th International PLEA Conference, CEPT University, Ahmedabad, India, 16-18 December 2014.

26. Johnson, H.; Robinson, J. Atlante Mondiale Dei Vini; Mondadori Electa: Milan, Italy, 2014; ISBN 9788837099060.

27. Ribéreau-Gayon, P.; Dubourdieu, D.; Donèche, B. Trattato di Enologia Volume 1. Microbiologia del vino e Vinificazioni, Edagricole, 4th ed.; New Business Media: Milano, Italy, 2017; ISBN 885065507X.

28. Bonfante, A.; Terribile, F. Zonazione viticola. Un approccio su base fisica. In Proceedings of the Suolo e Vino Conference, Imola, Italy, 11-12 October 2006; pp. 49-57.

29. Ascione, F.; De Rossi, F.; Vanoli, G.P. Energy retrofit of historical buildings: Theoretical and experimental investigations for the modelling of reliable performance scenarios. Energy Build. 2011, 43, 1925-1936. [CrossRef]

30. Cornaro, C.; Puggioni, V.A.; Strollo, R.M. Dynamic simulation and on-site measurements for energy retrofit of complex historic buildings: Villa Mondragone case study. J. Build. Eng. 2016, 6, 17-28. [CrossRef]

31. Gagliano, A.; Nocera, F.; Patania, F.; Detommaso, M.; Sapienza, V. Deploy energy-efficient technologies in the restoration of a traditional building in the historical center of Catania (Italy). Energy Procedia 2014, 62, 62-71. [CrossRef]

32. Ramos Ruiz, G.; Fernández Bandera, C. Validation of Calibrated Energy Models: Common Errors. Energies 2017, 10, 1587. [CrossRef]

33. Willmott Cort, J.; Robeson Scott, M.; Matsuura, K. Short Communication A refined index of model performance. Int. J. Climatol. 2012, 32, 2088-2094. [CrossRef]

34. Italian Republic. Ministerial Decree 26 June 2015. Appx. A, Att. 1. Adeguamento del Decreto del Ministro Dello Sviluppo Economico, 26 Giugno 2009_Linee Guida Nazionali per la Certificazione Energetica Degli Edifici; OJ of the Italian Republic: Rome, Italy, 2015. Available online: https: //www.mise.gov.it/index.php/it/normativa/decreti-interministeriali/2032968-decreto-interministeriale-26giugno-2015-adeguamento-linee-guida-nazionali-per-la-certificazione-energetica-degli-edifici (accessed on 20 June 2020).

35. Lagüela, S.; Martínez, J.; Armesto, J.; Arias, P. Energy efficiency studies through 3D laser scanning and thermographic technologies. Energy Build. 2011, 43, 1216-1221. [CrossRef]

36. Bevilacqua, P.; Benevento, F.; Bruno, R.; Arcuri, N. Are Trombe walls suitable passive systems for the reduction of the yearly building energy requirements? Energy 2019, 185, 554-566. [CrossRef] 
37. Bevilacqua, P.; Bruno, R.; Arcuri, R. Green roofs in a Mediterranean climate: Energy performances based on in-situ experimental data. Renew. Energy 2020, 152, 1414-1430. [CrossRef]

38. Bruno, R.; Bevilacqua, P.; Cuconati, T.; Arcuri, N. Energy evaluations of an innovative multi-storey wooden near Zero Energy Building designed for Mediterranean areas. Appl. Energy 2019, 238, 929-941. [CrossRef]

39. Fabbri, A.; Morel, J.C. Earthen materials and constructions. Nonconventional and Vernacular Construction Materials; Woodhead Publishing Series in Civil and Structural Engineering; Woodhead Publishing: Cambridge, UK, 2013.

40. Giuffrida, G.; Caponetto, R.; Nocera, F. Hygrothermal Properties of Raw Earth Materials: A Literature Review. Sustainability 2019, 11, 5342.

41. Ogley, P.; Pickles, D.; Wood, C.; Brocklebank, I. Energy Efficiency and Historic Buildings: Insulating Solid Ground Floors; English Heritage: London, UK, 2012.

(C) 2020 by the authors. Licensee MDPI, Basel, Switzerland. This article is an open access article distributed under the terms and conditions of the Creative Commons Attribution (CC BY) license (http://creativecommons.org/licenses/by/4.0/). 